\title{
PERILAKU IBU DALAM PEMENUHAN KEBUTUHAN ASAH, ASIH DAN ASUH ANAK DENGAN LEUKEMIA
}

\author{
(Mother's Behaviour In Meeting The Needs Of Stimulation, Emotion And Physical \\ Children With Leukemia)
}

\author{
Praba Diyan Rachmawati*, IGM Reza Gunadi Ranuh**, Yuni Sufyanti Arief* \\ * Fakultas Keperawatan Universitas Airlangga Mulyorejo Kampus C Unair Surabaya \\ ** RSU Dr. Soetomo Surabaya \\ Email: diyanatha@gmail.com
}

\begin{abstract}
ABSTRAK
Pendahuluan: Anak-anak dengan leukemia memiliki kualitas hidup yang kurang baik. Perawatan dan pengobatan jangka panjang, efek samping dari pengobatan dan gejala dari penyakit leukemia akan berdampak pada kualitas hidup anak dengan leukemia. Orang tua memiliki peran penting dalam memenuhi kebutuhan dasar anak akan Asah, Asih dan Asuh. Terpenuhinya kebutuhan dasar anak dengan baik, kualitas hidup anak dengan leukemia akan meningkat. Metode: Desain yang digunakan dalam penelitian ini adalah observasional analitik. Populasi adalah ibu dari anak-anak leukemia di ruang hematologi anak, dilakukan pada selama 1 bulan tahun 2014. pengambilan sampel berturut-turut digunakan dalam penelitian ini. Sampel sejumlah 20 ibu yang memenuhi kriteria inklusi, variabel independen adalah karakteristik ibu, sumber efikasi diri, perawatan berpusat keluarga, efikasi diri orang tua dan variabel dependen adalah perilaku ibu dan kualitas hidup anak. Data dikumpulkan dengan menggunakan kuesioner dan dianalisis menggunakan PLS (Partial Least Square). Hasil: Hasil penelitian menunjukkan bahwa sumber efikasi diri berpengaruh terhadap efikasi diri, Efikasi diri dan karakteristik ibu berpengaruh langsung pada perilaku ibu. Perawatan berpusat keluarga tidak dapat secara langsung mempengaruhi perilaku ibu. Diskusi: Dapat disimpulkan bahwa model perilaku ibu dalam pemenuhan kebutuhan asah, asih dan anak dengan leukemia dapat dibentuk dari karakteristik ibu, sumber efikasi diri dan Efikasi diri orang tua. Efikasi diri orangtua dapat ditingkatkan terutama dengan meningkatkan mekanisme koping dan pengalaman orang lain.
\end{abstract}

Kata kunci: stimulasi, emosi, perilaku fisik ibu, anak-anak leukemia kualitas hidup

\begin{abstract}
Introduction: Children with leukemia have a poor quality of live. A long term periode of care, treatment, side effect of treatment and the symptom of the leukemia disease will have an impact on leukemia children quality of life. Parents have an important role in meeting the basic needs of the child by stimulation, emotion and physical. With the fulfillment of the basic needs of children, the quality of life of children with leukemia will increase. Method: Design used in this study was an observational analytic. The population was mother of leukemia children. Conducted a month on 2014. Consecutive sampling was used in this study. Sample were 20 mother who met in inclusion criteria. Independent variables were mother's characteristics, self efficacy source, family centre care, Parental Self efficacy and dependent variables were mother's behaviour and child quality of life. Data was collected using quetionnaire and analyzed using PLS (Partial Least Square) Regression. Result: Result showed that sources of self-efficacy influence on self-efficacy, self efficacy and mother's characteristics directly affects the mother's behaviour. Family centered care can't directly affect mother's behaviour. Discussion: It can be concluded that mother's behaviour model in stimulating, loving and physical caring children with leukemia can be formed from mother's characteristics, self efficacy source and Parental self efficacy. Parental self efficacy can be increased especially by improving coping mechanisms and vicarious experience.
\end{abstract}

Keyword: stimulation, emotion, physical, mother's behaviour, leukemia children quality of life

\section{PENDAHULUAN}

Anak dengan leukemia yang menjalani masa perawatan dan pengobatan juga memiliki keinginan serta kebutuhan untuk beraktivitas, melakukan hal yang sama dengan anak normal pada umumnya sesuai dengan tumbuh kembangnya. Pengobatan yang lama serta efek samping yang dirasakan oleh anak yang menjalani pengobatan leukemia dalam jangka waktu lama akan berdampak pada kualitas hidup anak baik dari segi fisik, emosional maupun sosial (Umiati, M., Rakhmawati, W., Simangunsong, B., Lukitowati, Fauzi, E.,
Setiawan, E. 2013; Eiser, C. Richard, E., Stride, C. 2005). Orang tua akan merasa bersalah, marah, lelah dan stres dalam menghadapi kondisi tersebut, oleh karena itu penyakit leukemia pada anak akan memberikan pengaruh dalam beberapa hal yang dialami orang tua yaitu dalam hal psikologis, emosi, ekonomi dan sosial (Jones, B 2012; Mussato 2006). Berbagai situasi ini menyebabkan orang tua anak dengan penyakit leukemia merasakan kesedihan yang berulang, mendalam dan permanen (Eakes 1995). Hal ini akan berpengaruh terhadap perilaku orang tua. Penelitian yang dilakukan di ruang Bona 1 dan Bona 2 RSUD Dr. Soetomo menunjukkan 
bahwa $64,3 \%$ orang tua memberikan perawatan pada anak leukemia yang menjalani kemoterapi dengan kategori sedang dan 7,1\% menunjukkan perawatan yang kurang (Quraniati 2013). Hasil pengamatan tentang kualitas perawatan orang tua di ruang hematologi anak RSUD Dr. Soetomo didapatkan $50 \%$ orang tua kurang dalam melakukan upaya stimulasi perkembangan anak, orang tua jarang bermain bersama anak serta memilih permainan yang tidak sesuai dengan kebutuhan perkembangan. Selain itu beberapa orang tua anak dengan kanker di Instalasi Rawat Inap (IRNA) anak RSUD Dr. Soetomo kurang memperhatikan kondisi emosi anak akibat penyakit dan pengobatan jangka panjang yang dijalani. Diperlukan upaya perawat dalam penerapan Family Centre Care (FCC) sebagai filosofi keperawatan anak untuk melibatkan dan memampukan orang tua sebagai upaya meningkatkan kualitas perawatan orang tua melalui optimalisasi pemenuhan kebutuhan dasar anak Asah, Asih dan Asuh (3A). Hal ini sejalan dengan misi IRNA Anak RSU Dr. Soetomo Surabaya yaitu menerapkan asah, asih dan asuh dengan melibatkan orang tua (Care with Parent). Namun sampai saat ini perilaku ibu dalam pemenuhan kebutuhan asah, asih dan asuh untuk meningkatkan kualitas hidup anak dengan leukemia belum dapat dijelaskan.

Kualitas hidup anak akan menurun karena nyeri yang dirasakan, kehilangan aktitivitas sehari-hari yang menyenangkan serta ketakutan akan masa depan, begitu pula pada orang tua, orang tua akan merasakan depresi dan kecemasan yang tinggi serta mengalami penurunan kualitas hidup yang signifikan bila dibandingkan dengan populasi orang tua anak normal (Eiser, C. Richard, E., Stride, C. 2005). Stres dan berbagai permasalahan psikologis yang dialami orang tua menurunkan Parental Self Efficacy (PSE) (Guimond, A, B., Wilcox, M, J., Lamorey 2008; Hastings, R. P., \& Brown 2002). Self efficacy berpengaruh terhadap perilaku seseorang Parental Self Efficacy (PSE) (Peterson, S, J., Bredow, T 2004) sehingga akan berpengaruh pada kualitas orang tua dalam memberikan perawatan terhadap anak (Jones, T. L., \& Prinz 2005).merupakan hal yang dapat digali dari orang tua dimana orang tua merasa berkompeten dan percaya diri akan kemampuan, ketrampilan serta pengetahuan dirinya untuk merawat anak dengan penyakit kronis ketika anak harus menjalani penyakit dan perawatan dalam jangka waktu yang lama (Guimond, A, B., Wilcox, M, J., Lamorey 2008). Self efficacy ini dapat merubah perilaku seseorang (Bandura 1977; Peterson, S, J., Bredow, T 2004) dengan adanya kekuatan dan keyakinan akan sebuah harapan bahwa diri seseorang mampu menghadapi akan terwujud suatu perilaku yang postif. Hal ini dapat diterapkan pada kondisi penyakit kronis yang dialami oleh anak, dimana menunjukkan bahwa efikasi diri orang tua merupakan mediator untuk meningkatkan kualitas perawatan orang tua secara optimal untuk menigkatkan kualitas hidup anak.

Irmawati, M., Irwanto, Cahyadi (2012) menyebutkan bahwa target pelaksanaan tenaga kesehatan dalam penanganan penyakit kronis tidak hanya diprioritaskan dari segi pengobatan saja, tetapi juga perawatan. Salah satu tujuan perawatan dari anak dengan penyakit kronis adalah mengoptimalkan tumbuh kembang anak baik dalam perkembangan fisik, kognitif maupun psikososial. Orang tua memiliki peranan penting dalam memenuhi kebutuhan dasar anak untuk dapat bertumbuh dan berkembang, yaitu dengan Asah, Asih dan Asuh (3A). Kebutuhan dasar anak akan asah merupakan pemenuhan kebutuhan stimulasi anak, asih adalah pemenuhan kebutuhan anak akan emosi atau kasih sayang sedangkan asuh adalah pemenuhan kebutuhan fisik anak (Soetjiningsih 2005). Terpenuhinya kebutuhan dasar anak maka kualiatas hidup anak terutama anak dengan leukemia akan meningkat.

Perawat dalam upaya meningkatkan kualitas hidup anak memiliki peranan juga untuk menggali kekuatan yang ada dalam orang tua, meningkatkan kepercayaan diri orang tua dan kemampuan untuk merawat anak dengan kondisi penyakit kronis (Soetjiningsih 2005). Perilaku merawat anak dengan prinsip asah, asih dan asuh orang tua terhadap anak dengan leukemia ditentukan oleh bagaimana self efficacy orang tua. Berawal dari pemikiran dan fenomena tersebut diatas dirasa perlu adanya pengembangan suatu model perilaku ibu dalam pemenuhan kebutuhan Asah, Asih, Asuh (3A) untuk meningkatkan kualitas hidup anak leukemia. Kerangka penelitian yang akan digunakan dalam penelitian ini adalah dengan pendekatan teori keperawatan middle range Self Efficacy Barbara (Peterson, S, J., Bredow, $\mathrm{T}$ 2004) melalui pemenuhan kebutuhan dasar 
anak Asah, Asih, Asuh (3A) (Soetjiningsih 2005).

\section{BAHAN DAN METODE}

Jenis penelitian yang digunakan dalam penelitian ini adalah eksplanatif observational dengan pendekatan cross sectional. Populasi terjangkau seluruh ibu dengan anak terdiagnosa leukemia yang sedang di rawat di ruang Hematologi anak RSUD Dr. Soetomo, Sampel penelitian adalah Ibu dengan anak terdiagnosa leukemia yang memenuhi kriteria inklusi, yaitu Ibu bisa membaca dan menulis, Ibu yang sedang menunggu anak selama di rawat di rumah sakit, Ibu dengan anak leukemia yang terdiagnosa $\geq 4$ minggu dan Ibu dengan anak leukemia yang berusia 6-12 tahun

Teknik pengambilan sampel yang digunakan non probability sampling, yaitu consecutive sampling dimana penetapan subyek yang memenuhi kriteria penelitian dimasukkan dalam penelitian sampai kurun waktu tertentu (Nursalam 2013). Kurun waktu yang ditetapkan dalam penelitian ini adalah 1 bulan. Variabel independen dalam penelitian ini adalah sumber self efficacy (performance accomplisment, vicarious experience, verbal persuassion, mekanisme koping), karakteristik personal ibu (usia, tingkat pendidikan, lama merawat anak, kualitas hidup ibu, kesedihan kronis ibu, kecerdasan emosional ibu), dan parental self efficacy. Penelitian dilaksanakan selama 1 bulan pada tahun 2014.

Analisis yang digunakan dalam penelitian ini adalah dengan analisis bivariate, dimana dilakukan terhadap dua variabel yang diduga berhubunagn atau berkorelasi dan dengan Partial Least Square (PLS), dimana digunakan untuk menguji model hipotesis yang diusulkan dalam penelitian ini. Pengujian hipotesis dilakukan dengan uji statistic $\mathrm{t}$ ( $t$ test). Jika dalam pengujian ini diperoleh tvalue $>1,96$ (alpha 5\%) berarti pengujian significant, dan jika nilai t value $<1,96$ (alpha $5 \%$ ) berarti hasil tidak signifikan.

\section{HASIL}

Sebagian besar responden yang tidak memiliki performance accomplishments memiliki tingkat self efficacy yang rendah yaitu sebanyak 7 orang (35\%). Sebanyak 35\% responden memiliki persuasi verbal yang baik dan berada pada tingkatan parental self efficacy yang rendah. Lebih dari separuh responden (55\%) memiliki mekanisme koping yang negatif dengan tingkat self efficacy yang rendah.

Hasil penelitian ini menunjukkan bahwa sebagian besar berada pada rentang usia 20-40 tahun sebanyak $70 \%$, dari jumlah tersebut $50 \%$ responden memiliki self efficacy dalam kategori yang rendah. Indikator pendidikan menunjukkan bahwa pendidikan responden sebagian besar adalah berpendidikan rendah memiliki self efficacy dalam kategori yang rendah yaitu sebanyak 8 ibu (40\%).

Pada indikator lama orang tua merawat anak dengan leukemia diketahui bahwa sebagian besar orang tua merawat anak dengan leukemia selama 1-3 bulan, dari jumlah tersebut $30 \%$ berada pada tingkat self efficacy yang rendah. Indikator kesedihan kronis yang dirasakan orang tua menunjukkan bahwa 55\% orang tua yang mengalami kesedihan kronis dalam tingkatan sedang memiliki tingkat self efficacy yang rendah. Pada indikator kualitas hidup orang tua menunjukkan bahwa sebagian besar responden berada pada kategori kualitas hidup yang buruk berada pada rentang self efficacy pada kategori yang rendah yaitu sebanyak 8 orang $(40 \%)$.

Asosiasi faktor personal ibu dengan perilaku ibu dalam pemenuhan kebutuhan Asah, Asih dan Asuh pada anak dengan leukemia menujukkan bahwa indikator pendidikan menunjukkan bahwa sebagian besar ibu dengan pendidikan rendah memiliki perilaku asih maupun asuh dalam kategori baik, yaitu sebanyak 7 orang (35\%), begitu pula dengan asah juga dalam kategori baik yaitu sebanyak 6 orang responden (30\%). Kualitas hidup ibu dalam kategori buruk memiliki perilaku perawatan asah yang kurang baik (40\%), asih dalam kategori yang kurang baik (30\%), asuh dalam kategori kurang baik $(30 \%)$.

Responden yang memiliki self efficacy dalam kategori rendah memiliki perilaku asah dalam kategori yang kurang baik (55\%), Asih dalam kategori yang rendah (35\%) dan asuh juga dalam kategori yang rendah $(40 \%)$. FCC dalam kategori baik mempengaruhi $45 \%$ responden untuk berperilaku pemenuhan asah dalam kategori baik, Separuh responden $(50 \%)$ memiliki perilaku asih dalam kategori baik dan lebih dari separuh responden (55\%) yang memiliki perilaku asuh dalam kategori baik. 


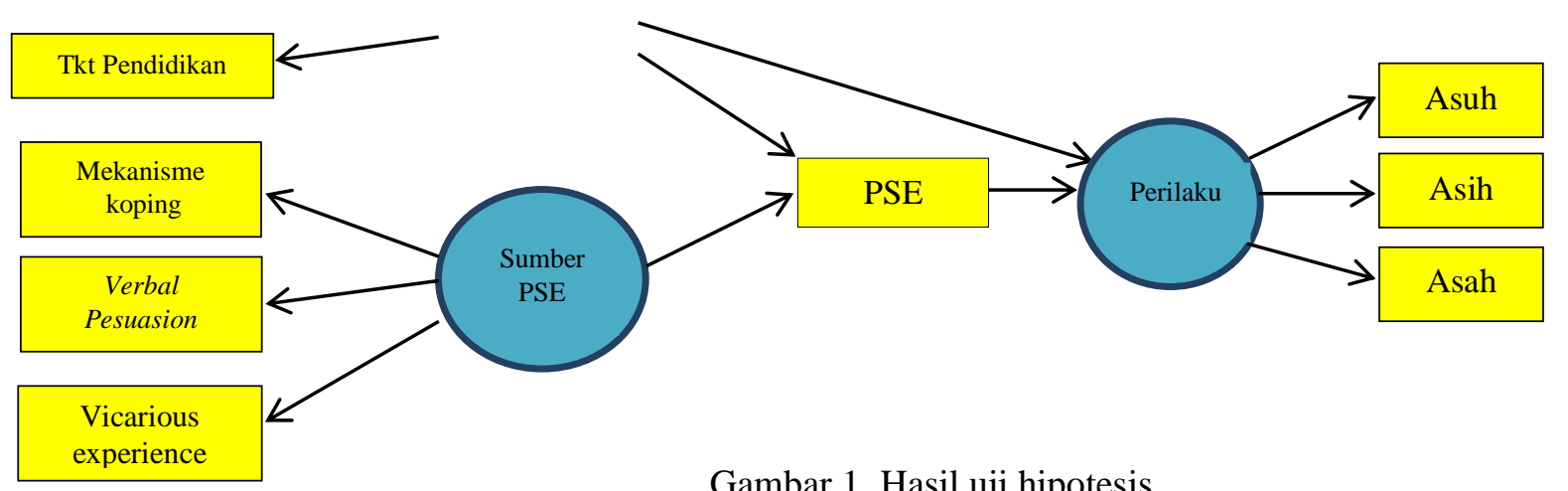

Gambar 1. Hasil uji hipotesis

Faktor personal semula tersusun atas usia, tingkat pendidikan, kesedihan kronis, lama diagnosa anak dan kualitas hidup ibu. Hasil uji statistik dengan menggunakan PLS menunjukkan bahwa usia, dan kesedihan kronis yang dialami ibu tidak menunjukkan hasil yang signifikan sehingga indikator penyusun tersebut dihilangkan. Begitu pula indikator penyusun sumber self efficacy dimana semula sumber self efficacy menurut teori dari (Bandura A 1994) tersusun atas 4 komponen yaitu performance accomplishment, vicarious experience, verbal persuasion dan mekanisme koping, namun hasil penelitian ini menunjukkan performance accomplishment tidak signifikan dalam membentuk sumber self efficacy sehingga indikator tersebut dihilangkan. Semua variabel dalam gambar diatas menunjukkan pengaruh yang siginifikan sesuai dengan kerangka yang direncankan, kecuali pada variabel lingkungan (FCC) tidak menunjukkan adanya pengaruh yang signifikan dengan perilaku ibu, sehingga variabel lingkungan (FCC) dihilangkan

\section{PEMBAHASAN}

Hasil penelitian ini menunjukkan bahwa pengalaman langsung (performance accomplishment) tidak membentuk sumber self efficacy ibu. Menurut Bandura A (1994) performance accomplishment merupakan salah satu penyusun sumber self efficacy, namun dalam penelitian ini tidak sesuai dengan teori tersebut. Performance accomplishment menurut (Bandura A 1994) adalah pengalaman menguasai suatu prestasi atau keberhasilan yang pernah dicapai pada masa lalu, dan faktor ini merupakan faktor utama dalam membentuk keyakinan seseorang akan kemampuannya dibandingkan dengan sumber self efficacy yang lain. Semua Ibu yang menjadi responden dalam penelitian ini tidak mempunyai pengalaman sebelumnya mempunyai anak dengan kondisi penyakit kronis, dimana anak dengan penyakit kronis membutuhkan perawatan dalam jangka waktu pengobatan dan masuk rumah sakit lebih dari 3 bulan (Wong, D.L., Hokenberry-eaton, M., Wilson, D., Winkelstein, M. L., Schwartz 2010). Hal inilah yang menyebabkan performance accomplishment tidak dapat menjadi faktor yang membentuk sumber self efficacy dalam penelitian ini. Performance accomplisment ibu dalam kategori baik disebabkan karena para ibu yang menjadi inklusi dalam penelitian ini telah melakukan perawatan pada anak minimal 1 bulan, dengan perawatan minimal 1 bulan ibu akan memiliki pengalaman.

Jumlah terbanyak responden tidak memiliki vicarious experience (pengalaman tidak langsung) dan memiliki tingkat self efficacy yang rendah, begitu pula terdapat responden yang memiliki vicarious experience juga memiliki self efficacy dalam kategori tinggi. Penelitian ini menunjukkan hasil bahwa vicarious experience ini menduduki urutan kedua yang menjadi indikator pembentuk sumber self efficacy, serta mempunyai skor yang cukup tinggi. Hasil analisis pada diskusi kelompok menunjukkan bahwa yang dapat menguatkan keyakinan ibu adalah pengalaman dari ibu lain yang memiliki masalah sama.

Vicarious experience merupakan pengalaman yang diperoleh dari orang lain yang memiliki karakteristik sama, dapat melewati atau melakukan dengan berhasil (Bandura A 1994). Menurut (Peterson, S, J., Bredow, T 2004) bahwa apabila seorang individu tidak memiliki pengalaman sendiri maka individu tersebut akan belajar dari pengalaman sukses orang lain. Berdasarkan hasil dan pembahasan sebelumnya Ibu yang menjadi responden dalam penelitian ini tidak memiliki pengalaman sendiri sebelumnya mempunyai anak dengan penyakit kronis, sehingga para ibu yang menjadi responden penelitian ini banyak mempelajari pengalaman 
berhasil dari orang lain, sehingga dapat membangkitkan keyakinan pada diri ibu bahwa juga akan bisa merawat anak dengan leukemia dengan baik.

Persuasi verbal dalam penelitian ini menujukkan hasil bahwa jumlah terbanyak adalah responden yang mempunyai persuasi vebal yang baik namun memiliki tingkat self efficacy yang rendah. Hasil uji statistik juga menunjukkan bahwa persuasi verbal memiliki nilai yang kecil dalam membentuk sumber self efficacy, dengan persuasi verbal seseorang akan mendapat pengaruh atau sugesti bahwa akan mampu mengatasi masalah-masalah yang akan dihadapi. Seseorang yang senantiasa diberikan keyakinan dan dorongan untuk sukses, maka akan menunjukkan perilaku untuk mencapai kesuksesan tersebut, begitupun sebaliknya dan keyakinan seseorang (Bandura A 1994). Persuasi verbal ini memberikan dorongan pada seseorang namun tidak menunjukkan pengalaman yang nyata yang dapat diamati. Hal ini sesuai dengan hasil diskusi kelompok bahwa ibu dengan anak leukemia seringkali mendapat persuasi secara verbal oleh orang lain yang memilki pengalaman masa lalu yang tidak dapat diamati oleh ibu pada saat ini. Hal ini menunjukkan bahwa tidak ada gambaran nyata yang dapat diamati oleh ibu untuk dapat dibentuk sebagai proses belajar untuk meningkatkan ketrampilan ibu dalam memberikan perawatan berbasis asah, asih dan asuh pada anak leukemia. Menurut (Bandura A 1994) seseorang akan meningkat keyakinannya dengan mengamati orang lain yang memilki karakteristik sama sukses melakukan sesuatu yang sama. Pengamatan dari peneliti responden dalam penelitian ini berada pada ruang kelas 3 yang berada di bangsal, sehingga aktifitas seharihari yang dilakukan responden selama merawat anak mereka di rumah sakit sering diketahui dan diamati oleh satu sama lain secara nyata terutama dalam aspek Asuh. Sesuai dengan pernyataan responden ketika diskusi kelompok bahwa ketika berada dirumah sakit responden merasa tidak sendirian, banyak yang memiliki masalah sama dengan respoden dan dapat dengan sukses merawat anak mereka. Hasil diskusi kelompok menunjukkan pula bahwa responden selain mendapatkan persuasi verbal dari orang yang memiliki pengalaman dimasa lalu, juga mendapat persuasi verbal dari orang tua pasien yang lain, sehingga dengan adanya persuasi verbal dan vicarious experience dapaat mendukung self efficacy yang baik, namun dalam penelitian vicarious experience lebih mendominasi dalam membentuk sumber self efficacy.

Responden terbanyak dalam penelitian ini memiliki mekanisme koping yang negatif juga memilki self efficacy dalam kategori rendah. Menurut Bandura A (1994) seseorang untuk dapat yakin akan kemampuannya yaitu salah satunya adalah koping sesorang tersebut terhadap stressor yang dihadapi. Pengelolaan emosi dengan mengurangi stres dan perasaan positif akan merubah persepsi dan interpretasi seseorang akan kemampuan yang dimilikinya juga positif sehingga koping yang baik dapat menjadi cara untuk merubah self efficacy seseorang menjadi baik (Bandura A 1994). Koping dapat menjadi indikator dan cara untuk membentuk self efficacy. Responden dalam penelitian ini adalah ibu dengan anak yang menderita penyakit kronis, dimana membutuhkan perawatan dan pengobatan dalam jangka waktu yang lama. Stres yang dialami ibu diakibatkan karena keparahan penyakit anak (Wong, D.L., Hokenberry-eaton, M., Wilson, D., Winkelstein, M. L., Schwartz 2010), Orang tua dengan penyakit kanker diruang hematologi anak Bona 1 sebagian besar mengalami stres (Krisnana, I. 2012). Stres atau kondisi psikologis yang dialami ibu dapat mempengaruhi self efficacy ibu (Guimond, A, B., Wilcox, M, J., Lamorey 2008) untuk bangkit dan merawat anak leukemia dengan baik, dengan koping yang baik yang akan dapat menciptkan keyakinan akan kemampuan diri yang baik pula.

Terdapat pengaruh yang signifikan antara faktor personal ibu dengan parental self efficacy. Faktor personal ibu dalam rancangan penelitian ini sebelumnya tersusun dari faktor usia, tingkat pendidikan, lama merawat anak, kualitas hidup dan tingkat kesedihan kronis yang dialami, dari kelima faktor yang menyusun faktor personal ibu tersebut, faktor usia dan kesedihan kronis ibu tidak terbukti dapat membentuk faktor personal ibu serta hasil penelitian ini menunjukkan bahwa pendidikan adalah indikator yang paling besar dalam menyusun faktor personal.

Tingkat pendidikan responden dalam penelitian ini sebagian besar berada pada tingkat pendidikan rendah (SD dan SMP) dan memiliki self efficacy yang rendah. Hasil analisis statistik menunjukkan bahwa pendidikan ibu ini menjadi indikator yang paling mendominasi 
dalam membentuk faktor personal, hal ini disebabkan karena sebagian besar ibu tidak memiliki pendidikan yang tinggi. Menurut Bandura (1997) pendidikan merupakan salah satu faktor yang mempengaruhi self efficacy seseorang. Tingkat pendidikan seseorang yang tinggi lebih banyak mendapatkan pendidikan formal dibandingkan dengan seseorang dengan tingkat pendidikan yang lebih rendah, hal ini disebabkan karena dengan pendidikan formal yang lebih tinggi seseorang akan lebih banyak memiliki kesempatan untuk menghadapi berbagai persoalan yang memerlukan aspek kognitif dalam pemecahannya. Self efficacy merupakan suatu pembentukan yang melalui proses kognitif dalam diri seseorang. Ibu yang menjadi responden dalam penelitian ini sebagian besar berpendidikan rendah, responden yang berpendidikan rendah ini memiliki tingkatan self efficacy yang rendah.

Lama ibu merawat anak dalam penelitian ini lebih dari separuhnya berada pada rentang 1-3 bulan. Lama waktu ibu merawat anak dengan leukemia berkaitan dengan pengalaman ibu, menurut Bandura A (1994) pengalaman merupakan salah satu faktor yang berpengaruh dalam pembentukan self efficacy. Semakin lama ibu merawat anak dengan leukemia semakin banyak rintangan yang menjadikan suatu proses pembelajaran yang harus dilalui oleh ibu. Namun dalam penelitian ini menunjukkan bahwa ibu yang memiliki pengalaman 4-12 bulan memiliki nilai self efficacy yang sama rendahnya dengan ibu yang memiliki pengalaman merawat anak 1-3 bulan. Ibu atau orang tua selama merawat anak akan seringkali merasakan kekhawatiran akan kondisi kekambuhan anak yang tidak pasti, jadi meskipun ibu yang menjadi responden penelitian ini telah lama merawat anak dengan leukemia namun masih memiliki self efficacy yang rendah.

Sebagian besar ibu dengan kualitas hidup yang buruk ini memiliki PSE yang rendah. Menurut (Bandura A 1994) salah satu pembentukan self efficacy adalah melalui proses afektif, yaitu suatu proses pengontrolan terhadap stressor yang terjadi. Self efficacy yang rendah berkaitan dengan stres dan depresi yang dialami oleh seseorang (Hastings, R. P., \& Brown 2002) oleh karena itu seseorang yang memiliki mekanisme pengontrolan terhadap stresor yang kurang baik akan memiliki self efficacy yang rendah. Ibu dengan anak leukemia memiliki tingkat stres yang tinggi
(Masa'Deh, R., Collier, J., and Hall 2012) dan berbagai permasalahan psikologis yang menyertai (Mussato 2006). Menurut Eakes (1995) orang tua dengan anak penderita penyakit kronis memiliki berbagai permasalahan psikologis seperti shock, tidak percaya, berduka, marah, frustasi, sedih, bingung dan putus asa yang berlangsung mendalam, berulang, dan permanen. Teori keperawatan chronic sorrow menyebutkan bahwa salah satu manajemen internal dalam diri seseorang yang mengalami kesedihan kronis adalah dengan proses kognif, sehingga dari pernyataan ini nampak bahwa dengan manajemen internal yang kurang baik, dilihat dari self efficacy yang rendah akan memunculkan kesedihan yang terus berulang. Salah satu aspek penyusun kualitas hidup ibu adalah faktor mental emosional. Beberapa hasil ini menunjukkan bahwa ibu yang menjadi responden dalam penelitian ini belum memiliki pengontrolan terhadap stressor yang baik sehingga memiliki self efficacy yang rendah.

Hasil penelitian ini menunjukkan hasil yang signifikan adanya pengaruh antara faktor personal ibu (tingkat pendidikan dan kualitas hidup) dengan perilaku ibu dalam asah, asih dan asuh. Hasil penelitian ini juga menunjukkan bahwa indikator usia, lama merawat anak, kesedihan kronis tidak terbukti dapat membentuk faktor personal ibu.

Responden dalam penelitian ini sebagian besar adalah berpendidikan rendah. Responden yang berpendidikan rendah ini dari hasil tabel asossiasi menunjukkan bahwa terdapat nilai yang mendominasi yaitu ibu dengan pendidikan rendah memiliki perilaku pemenuhan kebutuhan asah, asih maupun asuh yang baik. Menurut Soetjiningsih (2005) menyatakan bahwa pendidikan orang tua merupakan faktor yang penting dalam pertumbuhan dan perkembangan anak, dengan pendidikan yang tinggi orang tua dapat lebih mudah menyerap informasi. Pernyataan ini kurang sesuai dengan hasil penelitian ini meskipun secara teori maupun penelitian yang menyatakan bahwa pendidikan yang tinggi akan berpegaruh terhadap perilaku yang baik, namun berbeda dengan situasi dimana tempat penelitian dilaksanakan. Notoadmodjo (2013) mengatakan bahwa perilaku merupakan totalitas peghayatan dan aktivitas yang merupakan hasil akhir dari rangkaian proses dalam diri manusia seperti perhatian, pegamatan, pikiran, ingatan maupun fantasi seseorang. Di tempat penelitian yaitu ruangan hematologi anak Bona 
1 RSUD Dr Soetomo merupakan ruangan kelas 3 dimana sangat mudah bagi masing-masing ibu untuk saling bertukar informasi dan pengalaman baik melalui panca indra maupun secara verbal. Family centre care merupakan suatu program dimana seorang perawat memampukan dan melibatkan keluarga dalam setiap asuhan keperawatan yang dilakukan terhadap anak, dengan family centre approach ini perawat dapat meningkatkan rasa percaya diri dan kemampuan orang tua dalam merawat anaknya (Soetjiningsih 2005), sehingga meskipun tingkat pendidikan responden dalam penelitian ini cenderung rendah namun memiliki aspek pendukung yang memadai untuk dapat meningkatkan pengetahuan maupun kemampuan ibu dalam memenuhi kebutuhan anak akan asah, asih maupun asuh.

Lama ibu merawat anak dengan leukemia di nilai mulai dari anak terdiagnosa leukemia hingga waktu penelitian. Hasil penelitian ini menunjukkan bahwa lama merawat anak dengan leukemia tidak signifikan dalam membentuk faktor personal ibu. Lama merawat anak tidak selalu menjamin baik buruknya perilaku ibu dalam penelitian ini. Terdapat faktor Internal dan eksternal yang dapat mempengaruhi perilaku seseorang (Notoadmodjo 2013). Model dari Resnick yang merupakan pengembangan dari teori self efficacy Bandura yang mendasari penelitian ini menampilkan lingkungan sebagai faktor eksternal sedangkan faktor personal sebagai faktor internal. Menurut Notoadmodjo (2013) dari segi faktor eksternal lingkungan merupakan faktor yang mendominasi terbentuknya perilaku seseorang. Lama merawat anak disini merupakan salah satu faktor internal dari ibu. Faktor internal maupun eksternal saling terkait untuk membentuk perilaku seseorang. Responden penelitian ini memiliki banyak dukungan dari lingkungan, hal ini dapat dilihat dari hasil penelitian bahwa responden memiliki vicarious experience atau pengalaman dari orang lain yang memiliki masalah sama, hasil diskusi kelompok juga menunjukkan bahwa dukungan berupa belajar dari pengalaman dari ibu lain yang memiliki masalah sama yang telah lebih dulu anaknya terdiagnosa leukemia. Selain itu di ruangan perawatan anak RSUD Dr Soetomo Surabaya telah menerapkan Family Centered Care yang dapat mempengaruhi personal ibu, dimana sesuai dengan model teori dari Resnick yang menunjukkan bahwa selain lingkungan dapat berpengaruh langsung terhadap perilaku, faktor lingkungan juga sebelum dapat mempengaruhi perilaku, faktor ini merubah atau mempengaruhi faktor personal terlebih dahulu kemudian bisa merubah perilaku.

Hasil penelitian ini menunjukkan bahwa jumlah rerata terbanyak responden adalah responden yang memiliki kualitas hidup yang buruk dan memiliki perilaku pemenuhan kebutuhan asah, asih dan asuh dengan kualitas yang buruk pula. Penelitian ini dapat diketahui bahwa kualitas hidup ibu yang menjadi responden dalam penelitian ini sebagian besar adalah memiliki kualitas hidup yang buruk. Penelitian ini sesuai dengan hasil penelitian Eiser, C. Richard, E., Stride, C. (2005) bahwa kualitas hidup ibu anak dengan penyakit kronis akan menurun. Kualitas hidup ibu menurut Ware, J, E., Gandek (1998) terdiri dari fungsi kesehatan fisik, keterbatasan peran karena kesehatan fisik, nyeri, persepsi kesehatan secara umum, fungsi sosial, masalah emosional, psikis dan vitalitas. Dimensi kualitas hidup memiliki aspek yang cukup luas, yaitu aspek masalah fisik maupun psikologis. Menurut Notoadmodjo (2013) mengatakan kondisi emosi seseorang dapat mempengaruhi perilaku, karena emosi akan mempengaruhi pikiran dan daya nalar seseorang.

Hasil pengambilan data menunjukkan bahwa sebagian besar ibu yang memiliki self efficacy rendah juga memiliki perilaku asah, asih dan asuh yang rendah juga. Hasil uji statistik dalam penelitian ini menujukkan pula adanya pengaruh yang signifikan antara PSE dengan perilaku ibu dalam asah, asih dan asuh.

Menurut (Bandura A 1994) efficacy adalah keyakinan seseorang akan kemampuan dirinya dalam melakukan suatu aktivitas tertentu untuk mencapai suatu tujuan, menghadapi suatu tantangan atau bangkit dari masalah. Parental Self Efficacy (PSE) didefinisikan oleh Guimond, A, B., Wilcox, M, J., Lamorey (2008) sebagai persepsi orang tua akan kemampuan dirinya dalam menjalankan tugasnya sebagai orang tua terhadap anaknya secara efektif. Hal ini sejalan dengan Peterson, S, J., Bredow, T (2004) yang menyebutkan bahwa self efficacy akan berpengaruh terhadap perilaku seseorang.

Bandura (1994) mengatakan bahwa self efficacy akan melalui suatu proses dalam diri individu yaitu proses kognitif, motivasional, afektif dan seleksi. Melalui proses kognitif yaitu self efficacy mempengaruhi bagaimana pola pikir sehingga dapat mendorong atau menghambat perilaku seseorang. Proses ini sejalan dengan pendapat Gist \& Mitchell 
(1992) dalam Peterson, S, J., Bredow, T (2004) bahwa sebelum terbentuk suatu perilaku terjadi proses dalam diri seseorang yaitu analisis dari tugas yang akan dilalui, analisis dari pengalaman yang dimiliki dan mengkaji berbagai kebutuhan yang diperlukan sehingga akan muncul keyakinan atau kesiapan seseorang dalam menghadapi suatu tantangan, dari sinilah kemudian terbentuk perilaku yang tepat (Resnick, 2004). Ibu dengan anak leukemia yang memiliki self efficacy tinggi akan terbentuk pola pikir akan tercapainya suatu kesuksesan yaitu harapan kesembuhan anak atau kualitas hidup anak yang baik, sehingga dengan terbentuknya pola pikir yang positif ini akan terwujud suatu hal yang positif pula, perawatan ibu yang berdasar pada asah, asih dan asuh dengan kualitas baik sehingga terwujud kualitas hidup anak yang baik.

Self efficacy merupakan hal terpenting dalam diri seseorang untuk membentuk sebuah motivasi yang kuat, menurut teori expectancyvalue menyatakan bahwa motivasi terbentuk melalui harapan, usaha yang dilakukan seseorang berdasarkan dari seberapa besar harapan yang ingin diraih (Bandura A 1994). Adanya kepercayaan self efficacy yang tinggi pada seorang ibu dengan anak yang terdiagnosa leukemia dimana harus melaukan perawatan dalam jangka waktu yang panjang akan melewati berbagai tantangan selama perawatan, dengan motivasi yang kuat akan terbentuk suatu komitmen serta tingkatan pencapaian harapan yang tinggi yaitu terwujudnya kualitas hidup anak yang baik sehingga terbentuk perilaku pemenuhan kebutuhan anak asah, asih dan asuh dengan kualitas yang baik.

Parental self efficacy dalam penelitian ini memiliki pengaruh yang signifikan dalam membentuk perilaku asah, asih dan asuh ibu dengan anak leukemia. Pengaruh yang signifikan ini salah satunya juga dibentuk oleh faktor personal yang mendasari self efficacy Ibu, yaitu usia, pendidikan, lama merawat anak, tingkat kesedihan dan kualitas hidup ibu, yang telah dibahas pengaruhnya pada sub bab sebelumnya.

Hasil penelitian menunjukkan bahwa mayoritas perawat mengaplikasikan Family Centerd Care (FCC) dengan baik. Hasil uji statistik menunjukkan tidak adanya pengaruh antara FCC dengan perilaku ibu. Teori middle range self efficacy dari Barbara Resnick (2004) dalam (Peterson, S, J., Bredow, T 2004) menunjukkan bahwa faktor lingkungan memberikan pengaruh pada perilaku, namun pada penelitian ini tidak dapat membuktikan model tersebut. Penelitian untuk menyusun model tersebut dilaksanakan di negara asing yang berbeda budaya dan karakteristik personalnya dengan penelitian ini. Teori middle range self efficacy oleh Barbara Resnick (2004) dalam Peterson, S, J., Bredow, $\mathrm{T}$ (2004) nampak bahwa lingkungan selain dapat langsung mempengaruhi perilaku juga dapat melalui jalur peningkatan karakteristik personal terlebih dahulu sebelum kemudian dapat meningkatkan self efficacy dan juga perilaku. Menurut Judge (1997) dalam Guimond, A, B., Wilcox, M, J., Lamorey (2008) pemberdayaan orang tua terbukti secara signifikan dapat meningkatkan parental self efficacy ibu sehingga meningkatkan peran sebagai orang tua dengan baik. Hal ini sejalan dengan Dust (1999) bahwa perlunya dukungan pada faktor personal orang tua untuk dapat meningkatkan perilaku sehingga dapat tercipta output yang baik pada anak melalui program FCC.

Menurut Soetjiningsih (2005) peran pelayanan kesehatan pada anak dengan penyakit kronis atau leukemia bukan hanya pada aspek peyembuhan tetapi juga perawatan, tujuannya adalah untuk mencegah dampak dari kondisi kesehatan kronis dan mengoptimalkan tumbuh kembang anak baik fisik, kognitif dan psikososial, untuk dapat mencapai tujuan ini diperlukan perawatan yang berorientasi kepada keluarga (Family Centered). Perawatan dengan prinsip FCC ini memberikan dukungan dalam hal mengetahui kekuatan yang ada dalam keluarga, meningkatkan rasa percaya diri dan kemampuan dalam merawat anak. Dua konsep dasar dalam asuhan berpusat keluarga adalah memampukan (empowerment) dan memberdayakan (enabling) (Wong, D.L., Hokenberry-eaton, M., Wilson, D., Winkelstein, M. L., Schwartz 2010). FCC memberikan informasi mulai dari yang dasar sampai dengan perkembangannya secara berkelanjutan, dengan tujuan agar keluarga dan anak dapat lebih efektif dalam perawatan dan pengambilan keputusan, menyediakan fasilitas pendukung baik yang formal maupun informal. Seperti contoh pendukung informal yaitu adanya support group, bekerja sama dengan pasien dan keluarga di semua tingkat pelayanan kesehatan (American Academic of Pediatric 2012).

Perawat telah mengaplikasikan filosofi keperawatan anak FCC dalam memberikan 
perawatan pada pasien anak di ruang Bona 1 RSUD Dr Soetomo Surabaya, dimana sejalan dengan misi IRNA Anak yaitu memberikan pelayanan profesional berprinsip pada ASUH, ASIH, ASAH dengan melibatkan orang tua (Care with parents). FCC yang diaplikasikan oleh perawat tidak dapat langsung merubah perilaku ibu dalam asah, asih dan asuh, namun harus merubah karakteristik personal dari ibu terlebih dahulu. Indikator pendidikan merupakan indikator pembentuk karakteristik personal ibu yang paling utama. Responden dalam penelitian sebagian besar memiliki pendidikan dalam kategori yang rendah, sehingga diperlukannya peran perawat dalam memberdayakan dan memampukan ibu dalam perawatan anak untuk meningkatkan pengetahuan maupun ketrampilan ibu dalam perawatan anak, sehingga dengan pengetahuan dan ketrampilan yang baik akan dapat merubah perilaku ibu.

\section{SIMPULAN DAN SARAN}

\section{Simpulan}

Model perilaku ibu dalam pemenuhan kebutuhan asah, asih dan asuh sebagai upaya peningkatkan kualitas hidup anak dapat disusun dari beberapa faktor yaitu sumber self efficacy, parental self efficacy dan faktor personal ibu dengan anak leukemia. Kualitas personal ibu dapat ditingkatkan melalui program family centered care. Parental self efficacy dapat ditingkatkan dengan cara memperbaiki sumber self efficacy terutama mekanisme koping dan dukungan berupa pengalaman orang lain.

\section{Saran}

Perlu adanya program diskusi kelompok secara terstruktur bagi orang tua dengan anak leukemia yang di fasilitasi secara kolaboratif oleh tenaga kesehatan, baik dokter, perawat, maupun tenaga kesehatan lain untuk saling bertukar pengalaman dan memecahkan permasalahan bersama berbasis pemenuhan kebutuhan dasar anak asah, asih dan asuh. Perawat perlu meningkatkan pengetahuan orang tua tentang gejala fisik dan efek samping pengobatan anak dengan leukemia serta cara perawatan fisik anak leukemia dengan pendekatan dimensi fisik kualitas hidup anak yaitu memantau respons anak terhadap pengobatan kemoterapi, mencegah infeksi, mencegah cedera yang dapat menyebabkan perdarahan, pemberian nutrisi, mengatasi nyeri, istirahat dan tidur. Perlunya peningkatan pengetahuan orang tua dengan pemberian edukasi tentang perkembangan anak usia sekolah dan stimulasi yang terarah dan aman untuk perkembangan anak usia sekolah dengan penyakit leukemia. Perlunya perawat memberikan edukasi kepada orang tua dengan anak leukemia tentang kondisi emosional anak dengan leukemia dan pemenuhan kebutuhan emosional anak yang meliputi kasih sayang, rasa aman, harga diri, kebutuhan sukses, mandiri, dorongan, mendapatkan kesempatan dan pengalaman dan rasa memiliki

\section{KEPUSTAKAAN}

Bandura, 1977. Self-efficacy: Toward a unifying theory of behavioral change. Psychological Review, 84, pp.191-215. Available at: www. Sciencedirect.com.

Bandura A, 1994. Self Efficacy. In V. S. Ramachaudran (Ed.). Encyclopedia of human behavior, , 4, pp.71-81. Available at:

http://www.uky.edu/ eushe2/Bandura/Ba ndura1994EHB.pdf.

Eakes, G., 1995. Chronic Sorrow: The Lived Experience of Parents of Chronically Mentally ill Individuals. Archives of Psychiatric Nursing, 9(2).

Eiser, C. Richard, E., Stride, C., B., 2005. Quality of life in children newly diagnosed with cancer and their Mothers. Health and Quality of life outcomes, 29(3).

Guimond, A, B., Wilcox, M, J., Lamorey, J., 2008. The Early Intervention Parenting Self-Efficacy Scale (EIPSES) Scale Construction and Initial Psychometric Evidence. Journal of Early Intervention, 30(4), pp.295-320.

Hastings, R. P., \& Brown, T., 2002. Behavior problems of children with autism, parental self-efficacy, and mental health. American Journal on Mental Retardation,, 107, pp.222-232.

Irmawati, M., Irwanto, Cahyadi, A., 2012. Penilaian Kualitas Hidup Anak Penderita Kanker. Jurnal Ners, 7(2).

Jones, B, L., 2012. The challenge of quality care for family caregivers in pediatric cancer care. Seminars in Ocology Nursing, 28(4), pp.213-1220.

Jones, T. L., \& Prinz, R.J., 2005. Potential roles of parental self-efficacy in parent 
and child adjustment: A review. Clinical Psychology Review, 25, pp.341-363.

Krisnana, I., 2012. Model asuhan keperawatan dengan pendekatan Creating Oportunity for Parent Empowerment (COPE) sebagai upaya menurunkan stres hospitalisasi orang tua dengan anak leukemia. Jurnal Ners, 7(2).

Masa'Deh, R., Collier, J., and Hall, C., 2012. Parental stress when caring for a child withcancer in Jordan: a cross-sectional survey. Health and Quality of Life Outcomes, pp.1-7. Available at: http://www.hqlo.com/content/10/1/88.

Mussato, K., 2006. Adaptation of Child and family to life with a chronic illness. Cambridge Journal, 16.

Notoadmodjo, 2013. Promosi Kesehatan dan Perilaku Kesehatan, Jakarta: Rineka Cipta.

Nursalam, 2013. Metodologi Peneliian Ilmu Keperawatan., Jakarta: Salemba Medika.: Salemba Medika.

Pediatric, A.A.O., 2012. Patient- and FamilyCentered Care and the Pediatrician's Role. Pediatrics, 129(2), pp.394-404. Available at: www.pediatrics.org.

Peterson, S, J., Bredow, T, S., 2004. Middle Range Theories Application to Nursing
Research, Philadelpia: Lippincot William $\&$ Wilkins.

Quraniati, N., 2013. Model empowerment sebagai upaya meningkatkan perilaku orang tua dalam perawatan anak leukemia dengan kemoterapi, Surabaya.

Soetjiningsih, 2005. Tumbuh Kembang Anak dan Remaj 2nd ed., Jakarta: Sagung Seto.

Umiati, M., Rakhmawati, W., Simangunsong, B., Lukitowati, Fauzi, E., Setiawan, E., T., 2013. Gambaran kualitas hidup anak usia 6-18 Tahun yang menjalani kemoterapi. Indonesian journal of cancer. Available at: Indonesianjournalof cancer.org.

Ware, J, E., Gandek, B., 1998. Overview of the SF-36 Health Survey and the International Quality of Life Assessment (IQOLA) Project for the IQOLA Project. J Clin Epidemiol, 51(11), pp.903-912. Available at: http://www.qualitymetric.com/WhatWeD o/GenericHealthSurveys/tabid/184/Defau lt.aspx.

Wong, D.L., Hokenberry-eaton, M., Wilson, D., Winkelstein, M. L., Schwartz, P., 2010. Buku Ajar Keperawatan Pediatrik, Jakarta: EGC. 